\title{
Optimizing College English Teaching Mode with Structuralism
}

\author{
Wang Wenhua \\ School of foreign languages Xi'an Shiyou University \\ Xi'an China \\ e-mail: wangwenhua@xsyu.edu.cn
}

\begin{abstract}
This paper tries to pick up the very essence of structuralism and together with other excellent methods to explore a new mode for English teaching. Through analyzing the importance of Audio-lingual Approach, Grammar Translation Method, a mode for college English teaching is designed, which improves the students' listening, speaking, reading and writing abilities through practice.

Keywords-Structuralism; Audio-lingual Approach; Grammar-Translation Method; College English; Teaching Mode
\end{abstract}

\section{INTRODUCTION}

Recent years college English teaching mode are constantly adjusted and reformed with the call of Ministry of Education of People's Republic of China, and one of the changes is to modify the current syllabus, which shifts the main point from reading comprehension to listening and speaking. With structuralism for reference, a new teaching mode is designed in our university based on the currently popular text book New Horizon College English and the two teaching methods: Audio-lingual Approach and Grammar-Translation Method.

\section{A. Structuralism}

Structuralism is one of the most popular and influential ideological trends in west, which is based on the cognitive theory of Swiss psychologist J.P. Piaget, who thinks that every cognitive activity has a certain cognitive structure and children's cognitive structures are different from adults, so all educators should base teachings on these rules. Then Bruner, an American educator, applies Piaget's cognitive structure to the reform of educational area and his work
Process of Teaching is once praised as "one of the most important and influential educational works".

Structuralism focuses on the study of teaching reform; its main ideas can be concluded as these: (1)Focusing on the development of students' intelligence and abilities during teaching process. (2)Paying attention to teaching the basic structure of every subject. Educators of structuralism regard knowledge as a system of structurally related elements. (3)Advocating early study. Educators of structuralism emphasize that teachers should actively create learning environment for students to study, and use gestures, pictures, to make the knowledge understood easier and clearer. (4)Advocating discovering-study. Students acquire knowledge through their own thinking, and during the process, teachers should provide some indications and inspire students to think and to discuss. (5)Playing assistant role in structural teaching. (6) Using spiral-curriculum to improve students. Educators of structuralism believe that teachers should master the basic structure of this course before having classes, and then modify the new information according to students' cognitive levels so that accepting degree will accord with students' cognitive levels.

\section{B. Influences on English Teaching}

Under the influence of structuralism, there are many teaching methods generated, such as Audio-lingual Approach.

In teaching, Audio-lingual Approach needs four steps to complete the whole teaching process. (1)Teachers sent out language signals through using pictures, gestures, modes and words to help express the meanings. (2)After students understand the new information, teachers should do it repeatedly, and then make students imitate. During the 
process of students' imitation teachers should correct the wrong places, and then let students practice the right ones.(3)Letting students repeatedly practices until they can recite them.(4)Changing the sentence structure then letting students practice, for instance, choosing some words phrases, and sentence pattern to make students describe a certain scenery or things and so on, so as to cultivate their abilities in real communication.

There are many advantages of Audio-lingual Approach. (1)Emphasizing practicality of learning foreign language and pay much attention on listening and speaking practice. (2)Forming language habits through a lot of practice. (3) Regarding the sentence pattern as the key point of learning language (4)Widely using contrastive way to analyze the difference between mother tongue and foreign language and to find out the difficult points during the process of learning language and then to solve these difficulties. (5)Applying a lot of modern teaching technologies to having classes. Although there are so many advantages in Audio-lingual Approach, there are still some weaknesses. For instance, it pays so much attention on the form of structure but ignores the meaning of the language itself. Compared with speaking and listening, the ability of writing and reading is relatively low.

\section{Ideas of Grammar-Translation Method}

Considering students are over 18 years old in universities and to have a better teaching mode, another way is introduced in the paper to make up for the disadvantages that Audio-lingual Approach has. It is Grammar-Translation Method. Although it isn't based on the Structuralism, it can also reflect some ideas similar to structuralism, and more importantly it can make up for the weaknesses of Audio-lingual Approach. and improve. Some positive ideas of Grammar translation are these: (1)Introducing native language into teaching which makes knowledge easier for students to understand. (2)Elaborate explanations of grammar are always provided with examples and emphasis on the development of students' intelligence and abilities. (3) Grammar instructions provide the rules for putting words together.
Audio-lingual Approach is speech-based, paying attention to the learners' verbal communicative development while Grammar-Translation Method puts its emphasis on the improvement of learners' reading and writing skills. So when we have classes, we can combine the two methods together to improve students' learning skills, and finally a better teaching result can be achieved.

\section{EXPERIMENT}

\section{A. Teaching Material}

New Horizon College English book is widely used in many universities and it has a logical structure, so it is chosen as the selected teaching material. In this book each unit consists of four parts: preface, Section A, Section B and Section C. Preface is a compendious introduction about the topic; Section A includes 3 parts: Pre-reading activity for speaking and listening; Passage A for practicing reading; Text Structure Analysis and Structure Writing serve the purpose of writing exercises. Section B has two parts: Reading Skills and Vocabulary. Section $\mathrm{C}$ is extensive reading for student to read more materials with similar topic.

Full consideration is given about the students' characteristics, so the material selected in the book is very interesting, informative, rich and varied. Each passage is about 700 words, which is not only fit for teacher to teach in 50 minutes but also easier for students to understand and master the very essence of passages.

\section{B. Subjects}

The students in our experiment classes just graduated from high school. They have already learned English for a few years, but most of them like doing some paper exercises and pay little attention to listening and speaking.

\section{Design}

College English is a required course and important for students. with the currently used text book and Audio-lingual Approach combined with Grammar-Translation Method, a new teaching mode is designed with the aims of helping students improve the abilities of listening and speaking and strengthen reading and writing skills. 
The specific procedures are showed as the following

diagram:

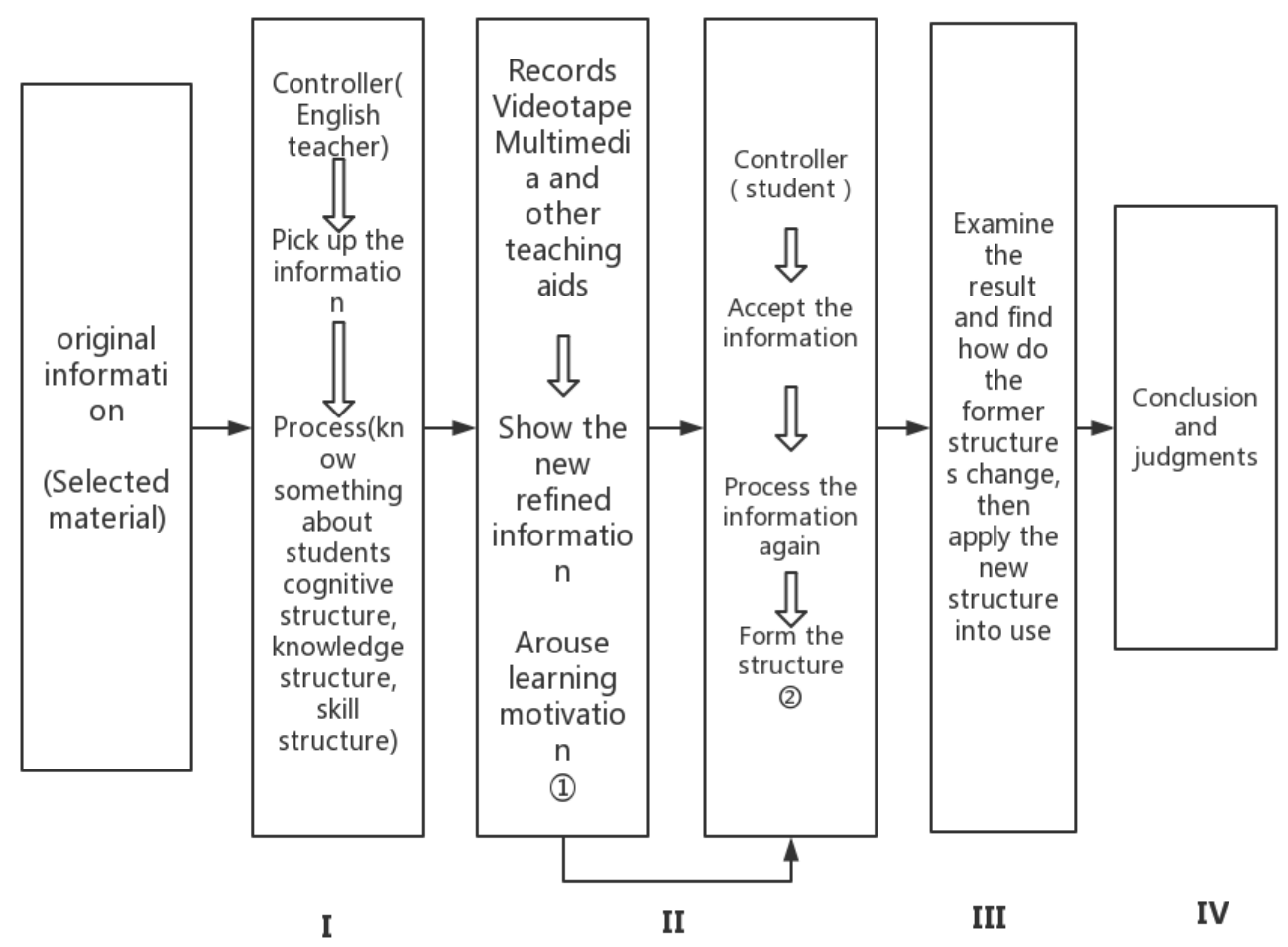

\section{1) Preparation Stage}

Before preparing a teaching plan, teachers consider the differences between students' schematic knowledge and new information, and try their best to narrow the gap between the two. For example, in preview part, teachers give students some background information to avoid some conflicts.

\section{2) Teaching Process}

With some background information, teachers integrate the cognitive structure with knowledge structure and assimilate students' concepts to help students put the new information into the former knowledge structure. Besides, teachers pay attention to students' initiative and enlighten them to explore knowledge by themselves. The specific procedures:

a) Teachers try to use English as much as possible during the whole class time, and ask some questions about the topic of the unit to inspire students to think at the very beginning of classes. b) For first listening, teachers arouse the students' attention to the questions. Then teachers discuss with students about the listening context. As for the second listening, teachers use some indications and hints to motivate students to answer questions about the topic or have a short speech to conclude the listening context.

c) For vocabulary part, teachers let students listen to the tape, and correct their pronunciation, after that, students follow the tape and read repeatedly.

d) After the warming-up activities, students get a lot about the topic, and through learning vocabulary they can understand the context better. Then, for passage A. Teachers ask students read by themselves and find the answers for some questions given by teachers. Of course they can ask teachers for help if problems come up. For difficult and confusing sentences or questions, teachers use native language to explain and analyse the structure and ask students to translate sentences, make new sentences by using the sentence patterns. Through those different exercises not 
only can students enforce the knowledge but also can improve their expressing ability.

e) Then students are given text structure analysis and structural writing as their homework. In this way students may have a deeper understanding of structure and it is helpful for students' reading skills and writing skills.

f) Finally, teachers use some investigative tables to help students get more information. To know more about behavior and manners of students and teachers, the "discovering-study investigation tables" is designed. And with the help of this, some information can be collected, thus a further research and analysis can be studied for further help.

TABLE I. DISCOVERING STUDY INVESTIGATION TABLE

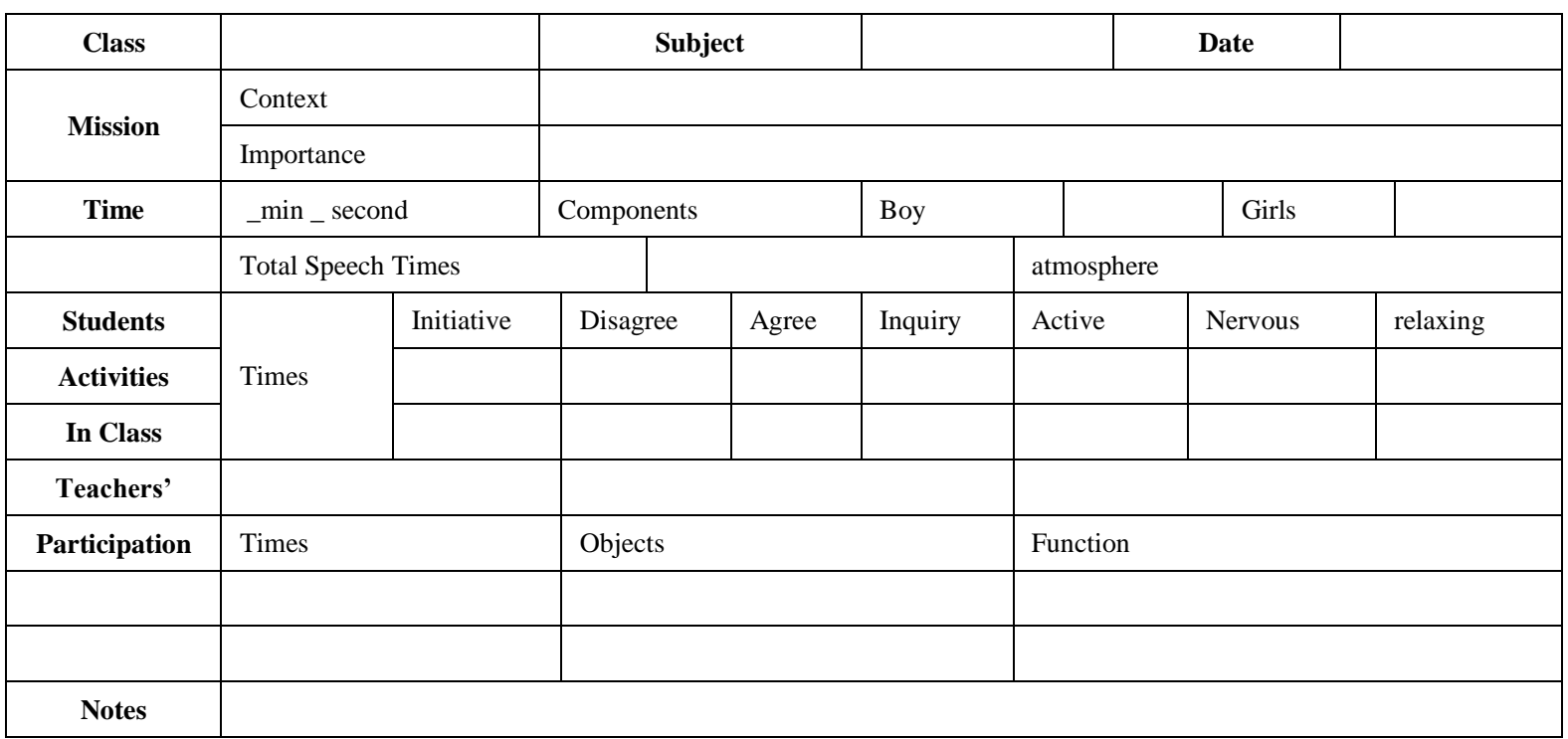

\section{3) Checking and Correcting Stage}

According to students' homework and some oral questions, teachers know how much students master, and have a further plan for the next class.

\section{4) Evaluating Stage}

As to evaluating students' performance, teachers divide students' homework into 3 levels: A, B and C. To level A students, teachers encourage them do better and attain higher goals, and to level Band $\mathrm{C}$ students, the teachers inspire them and give more aids. After classes, teachers inspire students to have different activities, such as English discussion, English song competition and English basket ball games. Through these varied and interesting activities, not only can these games help students cultivate more interests in English learning but also can improve their English abilities in daily life.
At this stage a questionnaire is needed to get more specific and exact information about students' structural awareness. Teaching strategies of structuralism are mainly reflected on the structural and logical thinking and the development of behavior. So, through a questionnaire about students' structural awareness, some useful information are to be collected about their evaluation of the teaching mode.

\section{EVALUATION}

After one semester of teaching practice, most of the students are satisfied with this mode. There are some data collected from the questionnaire. 
TABLE II. DATA COLLECTED FROM THE QUESTIONNAIRE

\begin{tabular}{|c|l|l|}
\hline Questions & Options & \multicolumn{1}{|c|}{ Answers: Yes } \\
\hline \multirow{3}{*}{1} & A & 0 \\
& B & $67.39 \%$ \\
& C & $32.61 \%$ \\
\hline \multirow{3}{*}{2} & A & $46.67 \%$ \\
& B & $35.56 \%$ \\
& C & $17.77 \%$ \\
\hline \multirow{3}{*}{3} & A & $45.65 \%$ \\
& B & $32.61 \%$ \\
& C & $21.74 \%$ \\
\hline \multirow{3}{*}{4} & A & $13.04 \%$ \\
& B & $76.09 \%$ \\
& C & $10.87 \%$ \\
\hline \multirow{2}{*}{5} & A & $58.70 \%$ \\
& B & $28.26 \%$ \\
& C & $13.04 \%$ \\
\hline \multirow{2}{*}{6} & A & $15.22 \%$ \\
& B & $15.22 \%$ \\
\hline
\end{tabular}

From those data in the chart above, we can clearly get the information that: about $80.44 \%$ students think this mode help them a lot in developing their language skills, and over $78.26 \%$ students can use structural ways to solve the problems in study; during the process of teaching, both teachers and students changed.

Teachers turn from "preachers" into initiators, promoters and learners, who promote students from three aspects: Inspire their interests and motivate their initiative. Give the clues between the old and the new knowledge to help students learn better. Arrange class time more rationally and activate students to listen, speak, read and write.

Students turn from passive learners to active founders and can use English.

\section{CONCLUSION}

Structuralism has a great influence on directing teaching methods, and it not only concentrates on students' initiative but also stresses teacher' guiding role. As for this new mode teaching, two remarkable points are clear:

1) The teaching mode stresses on the unity of teaching and learning so as to develop the students' intelligence and ability, and make full use of their potentialities and make them think on their own. The diagram below can show us the unity in the process of teaching and learning.

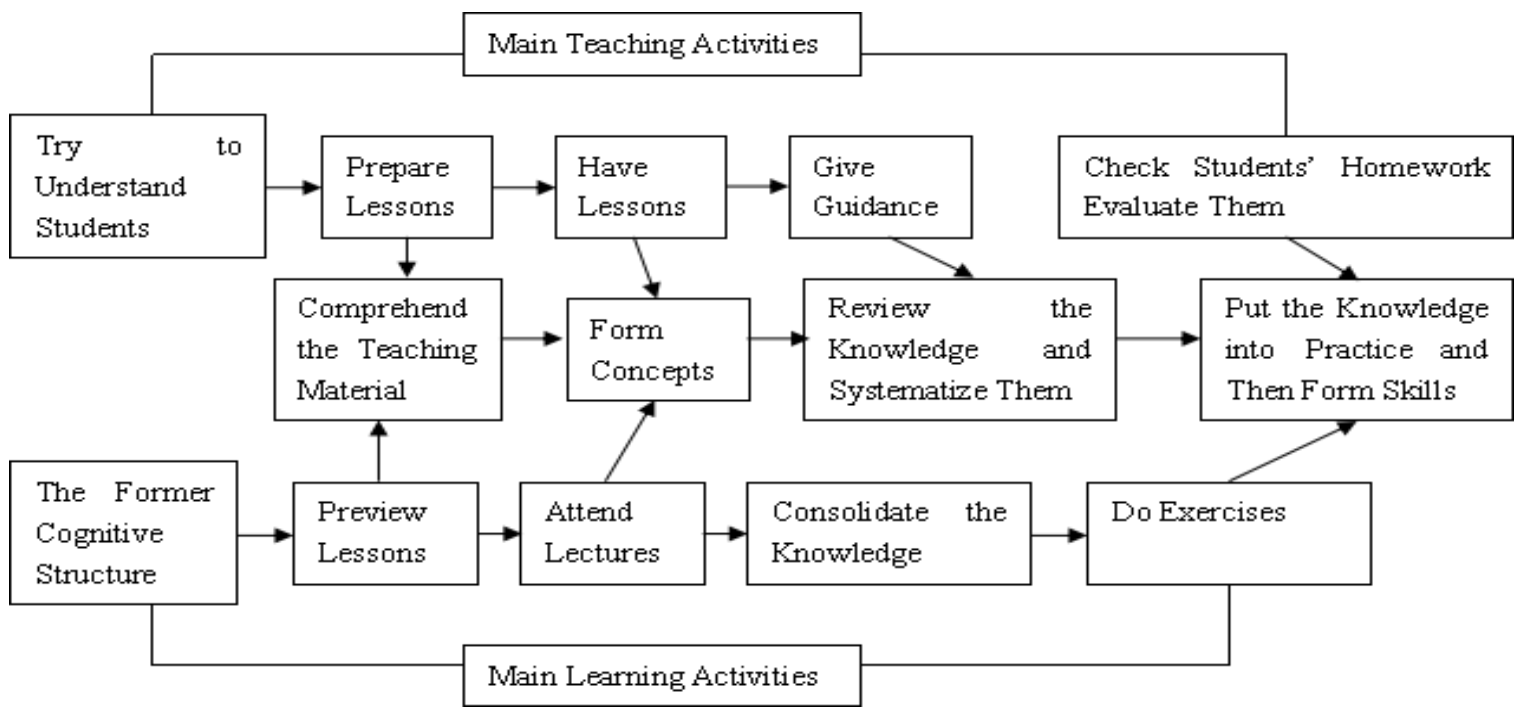

2) The teaching activities are a kind of dynamic process, in which teachers guide while the students initiate, and both teachers and students can have bilateral communication from many aspects. This process is mainly going on in the class, so teachers analyze students' background knowledge structure before preparing classes, then regulate and control the process.

Maybe there are still some weaknesses in this mode and it need to be improved. Anyway Learning English is a long 
way to go, so teachers need to have faith and try to make full use of more resources to make our students more excellent.

\section{REFERENCES:}

[1] Bruner. Process of Teaching[M]. Shanghai: Shanghai Renmin Book Office, 1973.

[2] English Department of Beijing Foreign Languages University. Research on Teaching College English in China[M]. Beijing:Peking University Press, 2001.

[3] Liu YUmei, Xiaosu. English Language Teaching: Theory and Practice[M]. Beijing: National Defend Industry Press, 2007.
[4] Ma Qinglin. The theoretical origins of American Linguistics[J]. Beijing:Foreign Language Teaching and Research Press. Volum 4, 2003.

[5] PeiDina. Third volumes of modern teaching theory [M]. Beijing : People's Education Press, 2005.

[6] Wang Qiang. A Course in English Language Teaching [M]. Beijing:Higher Education Press, 2006.

[7] Wu Shiying.. A course in foreign education history[M]. Beijing:People's Education Press, 1999.

[8] YuanSen, Zhang Meijuan. Foreign Language Teaching and Research [C]. Beijing:Xinhua Publishing House, 2000.

[9] Zheng Shutang. New Horizon College English(Reading and Writing) [Z]. Beijing:Foreign Language Teaching and Research Press, 2002.

[10] Zhao Shikai. A brief history of linguistics in Britain[M]. Shaihai:Shanghai Foreign Language Education Press, 1989. 